Supporting Information for:

\title{
Electrochemical and Spectroscopic Study of Mononuclear Ruthenium Water Oxidation Catalysts: A Combined Experimental and Theoretical Investigation
}

J.M. de Ruitera, R.L. Purchasea, A. Montia, C.J.M. van der Hama, M.P. Gulloc, K.S. Joyaa,b, M. D'Angelantonioc, A. Barbieric, D.G.H Hetterscheida, H.J.M. de Groota, F. Buda ${ }^{{ }^{*}}$

a Leiden University, Leiden Institute of Chemistry, Einsteinweg 55, 2300 RA, Leiden, The Netherlands

b Division of Physical Sciences and Engineering, KAUST Catalysis Center (KCC), King Abdullah University of Science and Technology (KAUST), 4700 KAUST, Thuwal 23955-6900, Saudi Arabia

'ISOF-CNR Area della Ricerca di Bologna, Via Pietro Gobetti 101, 40129 Bologna, Italy

*Corresponding author's e-mail: f.buda@chem.leidenuniv.nl

\section{Table of Contents}

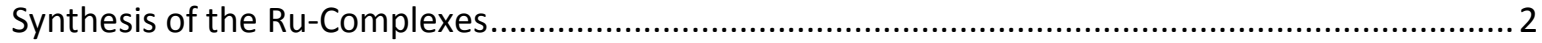

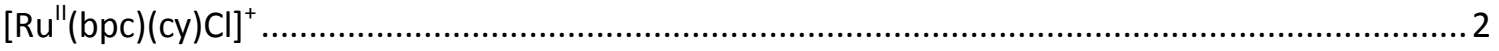

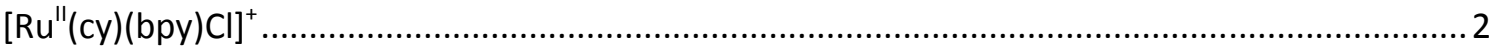

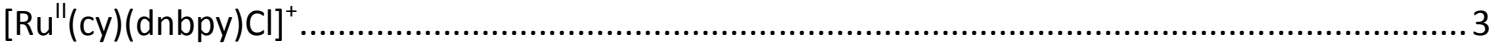

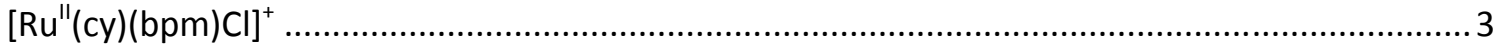

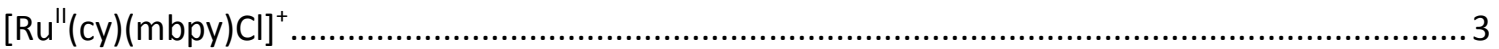

Calculated multiplicity proposed intermediates..................................................................

Validation theoretical TDDFT methodology .................................................................... 5

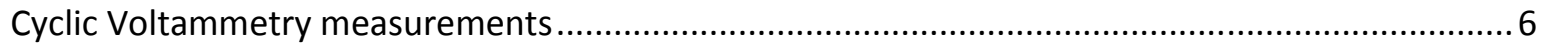

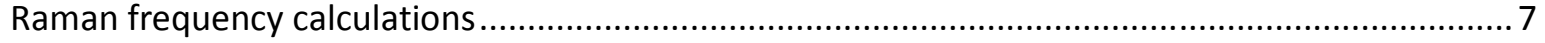

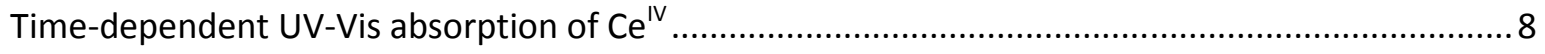

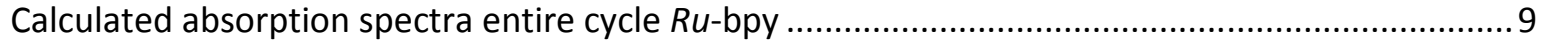

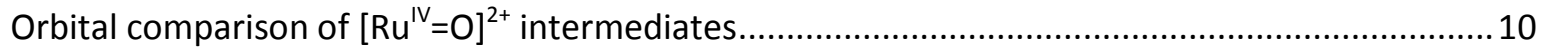

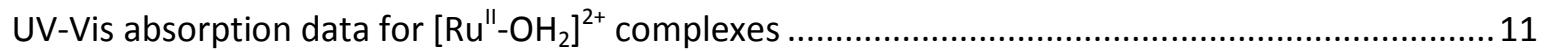

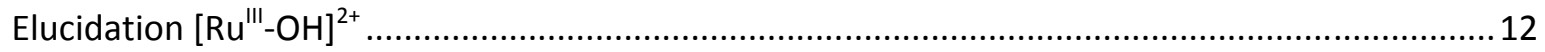

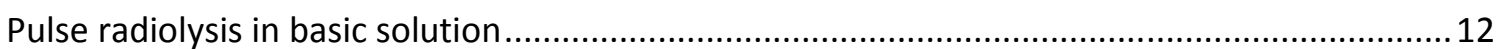

Pulse radiolysis in acidic solution........................................................................... 13

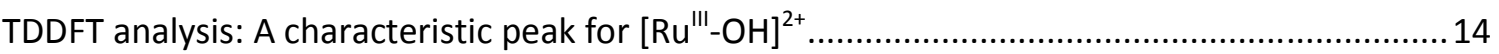

Pulse radiolysis in acidic solution: rate constant determination ...................................... 15

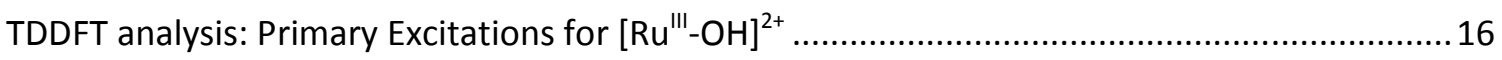

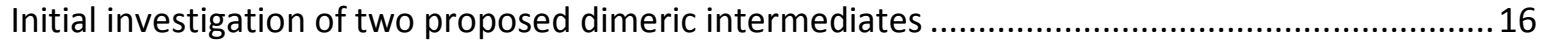

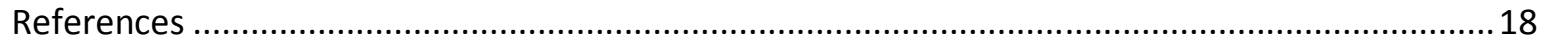




\section{Synthesis of the Ru-Complexes}

[RuCl 2 (p-cymene) $]_{2}$ dimer and $\mathrm{RuCl}_{3} \cdot n \mathrm{H}_{2} \mathrm{O}$ along with nitrogen-based ligands 2,2'-bipyridine (bpy), 4,4'-dinitro-2,2'-bipyridine (dnbpy), 4,4'-dicarboxylic acid-2,2'-bipyridine (bpc) and 2,2'-bipyrimidine (bpm) were obtained from Sigma-Aldrich Co. The aqua form of the catalysts $\left[\mathrm{Ru}(\mathrm{cy})(\mathrm{L})\left(\mathrm{H}_{2} \mathrm{O}\right)\right]^{2+}$ was obtained directly in situ dissolving the starting compound $\left[\mathrm{Ru}^{\prime \prime}(\mathrm{cy})(\mathrm{L})(\mathrm{Cl})\right] \mathrm{Cl}$ in aqueous solution (1 M $\mathrm{H}_{2} \mathrm{SO}_{4}$ for spectrophotometric measurements and water for pulse radiolysis) for 24 hours. CAN was dried under vacuum and used to prepare acidic (sulphuric acid, $\mathrm{H}_{2} \mathrm{SO}_{4}$ Fluka) solutions. All the solutions were prepared with distilled water that had been passed through a Millipore ultrapurification system. Ru-catalysts were synthesized in argon/nitrogen atmosphere. The synthesis of the $\left[R u^{\prime \prime}(\mathrm{cy})(\mathrm{L})(\mathrm{Cl})\right] \mathrm{Cl}$ compounds is detailed below.

Table S1. Summary of the complexes considered in this work

\begin{tabular}{|c|c|c|c|c|}
\hline Complex & Chloro complex & Colour & Ligand & Amount of ligand added \\
\hline$R u$-bpy & {$\left[\mathrm{Ru}^{\prime \prime}(\mathrm{cy})(\mathrm{bpy}) \mathrm{Cl}\right]^{+}$} & orange-yellow & 2,2'-bipyridine & bpy: $0.156 \mathrm{~g}, 1.0 \mathrm{mmol}$ \\
\hline$R u$-dnbpy & {$\left[\mathrm{Ru}^{\prime \prime}(\mathrm{cy})(\mathrm{dnbpy}) \mathrm{Cl}\right]^{+}$} & orange-red & $\begin{array}{l}\text { 4,4'-dinitro-2,2'- } \\
\text { bipyridine }\end{array}$ & dnbpy: $0.246 \mathrm{~g}, 1.0 \mathrm{mmol}$ \\
\hline$R u$-bpm & {$\left[\mathrm{Ru}^{\prime \prime}(\mathrm{cy})(\mathrm{bpm}) \mathrm{Cl}\right]^{+}$} & orange-brown & 2,2'-bipyrimidine & bpm: $0.158 \mathrm{~g}, 1.0 \mathrm{mmol}$ \\
\hline$R u$-mbpy & {$\left[\mathrm{Ru}^{\prime \prime}(\mathrm{cy})(\mathrm{mbpy}) \mathrm{Cl}\right]^{+}$} & orange-yellow & $\begin{array}{l}\text { 4,4'-dimethyl-2,2'- } \\
\text { bipyridine }\end{array}$ & mbpy:0.184g, $1.0 \mathrm{mmol}$ \\
\hline$R u-b p c$ & {$\left[\mathrm{Ru}^{\prime \prime}(\mathrm{cy})(\mathrm{bpc}) \mathrm{Cl}\right]^{+}$} & orange & $\begin{array}{l}\text { 4,4'-dicarboxylic } \\
\text { acid-2,2'-bipyridine }\end{array}$ & bpc: $0.244 \mathrm{~g}, 1.0 \mathrm{mmol}$ \\
\hline
\end{tabular}

\section{[RuII(bpc)(cy)Cl] ${ }^{+}$}

4,4'-dicarboxylic acid-2,2'-bipyridine (bpc: $0.244 \mathrm{~g}, 1.0 \mathrm{mmol}$ ) was dissolved in $0.5 \mathrm{~mL}$ water containing $\mathrm{NaOH}(0.08 \mathrm{~g}, 2.0 \mathrm{mmol})$ and $\mathrm{MeOH}(25 \mathrm{~mL})$ was added to it. This mixture was poured into a stirred mixture of $\left[\mathrm{RuCl}_{2}(p \text {-cymene })\right]_{2} \operatorname{dimer}(0.362 \mathrm{~g}, 0.5 \mathrm{mmol})$ in absolute $\mathrm{MeOH}(20 \mathrm{~mL})$. The whole reaction mixture was further stirred for 2 hours at $40-45^{\circ} \mathrm{C}$. The solution was cooled to room temperature and $\mathrm{pH}$ was lowered to $1-2$ by addition of $0.5 \mathrm{M} \mathrm{HCl}$. The free ligand was filtered off and the solvent mixture was evaporated under vacuum. The solid orange chloro complex $\left[(\mathrm{cy}) \mathrm{Ru}^{\prime \prime}(\mathrm{bpc}) \mathrm{Cl}\right] \mathrm{Cl}$ thus obtained was re-precipitated from $\mathrm{MeOH}$ or acetone by addition of ether/hexane. Yield $0.43 \mathrm{~g}, 78 \% .{ }^{1} \mathrm{H}$ NMR ( $\left.\mathrm{CD}_{3} \mathrm{OD}, 295 \mathrm{~K}, \delta \mathrm{ppm}, J \mathrm{~Hz}\right): 9.66\left(\mathrm{~d}, 2 \mathrm{H}, \mathrm{H}^{6,6^{\prime}}{ }_{\mathrm{bpc}}, J 5.76\right)$;

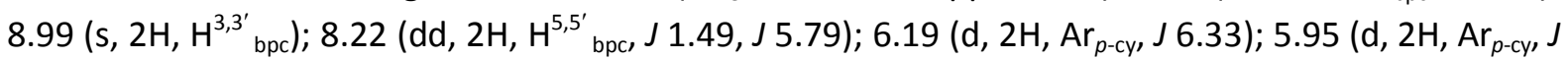
6.33); 2.66 (sep, $\left.1 \mathrm{H},-\mathrm{C} \underline{\mathrm{H}}\left(\mathrm{CH}_{3}\right)_{2 p-c y}\right) ; 2.27$ (s, 3H, $\left.\mathrm{CH}_{3 p-c y}\right) ; 1.06\left(\mathrm{~d}, 6 \mathrm{H},-\mathrm{CH}\left(\mathrm{CH}_{3}\right)_{2 p-c y}, J 6.91\right)$, Analysis found: C, 45.56\%; $\mathrm{H}, 4.41 \%$; N, 4.85\%. Calculated: C, 45.74\%; H, 4.36\%; N, $4.86 \%$ for $\mathrm{C}_{22} \mathrm{H}_{22} \mathrm{~N}_{2} \mathrm{O}_{4} \mathrm{Ru}_{1} \mathrm{Cl}_{2} \cdot 1.5 \mathrm{H}_{2} \mathrm{O}$ complex.

\section{[RuII(cy)(bpy)Cl] ${ }^{+}$}

2,2'-bipyridine (bpy: $0.156 \mathrm{~g}, 1.0 \mathrm{mmol}$ ) in $\mathrm{MeOH}(15 \mathrm{~mL})$ was added to a stirred mixture of $\left[\mathrm{RuCl}_{2}(p\right.$ cymene) $]_{2}$ dimer $(0.362 \mathrm{~g}, 0.5 \mathrm{mmol})$ in ab. $\mathrm{MeOH}(20 \mathrm{~mL})$. The mixture was further stirred for 1.5 hours at $40-45^{\circ} \mathrm{C}$. The solution was filtered with a sintered funnel of fine porosity and the solvent was evaporated under vacuum. The solid orange-yellow complex [Ru'(cy)(bpy)Cl] thus obtained was re-precipitated from acetone or $\mathrm{MeOH}$ by addition of ether/hexane. Yield $0.33 \mathrm{~g}, 71 \%$. ${ }^{1} \mathrm{H}$ NMR $\left(\mathrm{CD}_{3} \mathrm{OD}, 295 \mathrm{~K}, \delta \mathrm{ppm}, J \mathrm{~Hz}\right): 9.49\left(\mathrm{~d}, 2 \mathrm{H}, \mathrm{H}^{6,6^{\prime}}{ }_{\text {bpy }}, J 5.47\right) ; 8.51\left(\mathrm{~d}, 2 \mathrm{H}, \mathrm{H}^{3,3^{\prime}}\right.$ bpy, J 7.97); $8.23\left(\mathrm{t}, 2 \mathrm{H}, \mathrm{H}^{4,4^{\prime}}\right.$ bpy, J 7.86); $7.76\left(\mathrm{t}, 2 \mathrm{H}, \mathrm{H}^{5,5^{\prime}}{ }_{\text {bpy, }}, J 6.65\right) ; 6.13$ (d, 2H, $\mathrm{Ar}_{p-c y}, J 6.33$ ); 5.87 (d, 2H, $\operatorname{Ar}_{p-c y}, J 6.33$ ); 2.63 (sep, $\left.1 \mathrm{H},-\mathrm{C} \underline{\mathrm{H}}\left(\mathrm{CH}_{3}\right)_{2 p-c \mathrm{c} y}\right) ; 2.27$ (s, 3H, $\left.\mathrm{CH}_{3 p-c y}\right) ; 1.17$ (d, $\left.6 \mathrm{H},-\mathrm{CH}\left(\mathrm{CH}_{3}\right)_{2 p-c y}, \mathrm{~J} .91\right)$, Analysis found: $\mathrm{C}, 49.17 \%$; $\mathrm{H}, 5.30 \% ; \mathrm{N}, 5.60 \%$. Calculated: $\mathrm{C}, 50.0 \% ; \mathrm{H}, 5.04 \% ; \mathrm{N}, 5.83 \%$ for $\mathrm{C}_{20} \mathrm{H}_{22} \mathrm{~N}_{2} \mathrm{Ru}_{1} \mathrm{Cl}_{2} . \mathrm{H}_{2} \mathrm{O}$ complex. 


\section{[Ru' (cy)(dnbpy)Cl] ${ }^{+}$}

The orange-red chloro complex [(cy)Ru"(dnbpy)Cl] $]^{+}$was prepared in a similar manner as described for [Ru'(cy)(bpy)Cl] ${ }^{+}$using 4,4'-dinitro-2,2'-bipyridine (dnbpy: $0.246 \mathrm{~g}, 1.0 \mathrm{mmol}$ ) instead of 2,2'bipyridine. Yield $0.43 \mathrm{~g}, 78 \% .{ }^{1} \mathrm{H}$ NMR $\left(\mathrm{CD}_{3} \mathrm{OD}, 295 \mathrm{~K}, \delta \mathrm{ppm}, J \mathrm{~Hz}\right): 9.88\left(\mathrm{~d}, 2 \mathrm{H}, \mathrm{H}^{6,6^{\prime}}\right.$ dnbpy, J 6.81); 9.51 $\left(\mathrm{s}, 2 \mathrm{H}, \mathrm{H}^{3,3^{\prime}}{ }_{\text {dnbpy }}\right) ; 8.53\left(\mathrm{dd}, 2 \mathrm{H}, \mathrm{H}^{5,5^{\prime}}{ }_{\text {dnbpy }}, J 2.28, J 6.25\right) ; 6.28$ (d, 2H, $\left.\mathrm{Ar}_{p-c y}, J 6.37\right) ; 6.05$ (d, 2H, $\mathrm{Ar}_{p-c y} J$ 6.37); 2.75 (sep, $\left.1 \mathrm{H},-\mathrm{CH}\left(\mathrm{CH}_{3}\right)_{2 p-c y}\right) ; 2.28\left(\mathrm{~s}, 3 \mathrm{H}, \mathrm{CH}_{3 p-c y}\right) ; 1.11$ (d, 6H, $\left.-\mathrm{CH}\left(\mathrm{CH}_{3}\right)_{2 p-c y}, J 6.91\right)$, Analysis found: C, 41.43\%; H, 4.13\%; N, 9.50\%. Calculated: C, 42.11\%; H, 3.89\%; N, 9.82\% for $\mathrm{C}_{20} \mathrm{H}_{20} \mathrm{~N}_{4} \mathrm{O}_{4} \mathrm{Ru}_{1} \mathrm{Cl}_{2} \cdot \mathrm{H}_{2} \mathrm{O}$ complex.

\section{[RuII(cy)(bpm)Cl] $]^{+}$}

The orange-brown chloro complex $\left[\mathrm{Ru}^{\prime \prime}(\mathrm{cy})(\mathrm{bpm}) \mathrm{Cl}\right]^{+}$was prepared in a similar manner as described for [Ru'(cy)(bpy)Cl] $]^{+}$using 2,2'-bipyrimidine (bpm: $0.158 \mathrm{~g}, 1.0 \mathrm{mmol}$ ) instead of 2,2'-bipyridine. Yield $0.31 \mathrm{~g}, 67 \%$ \%. ${ }^{1} \mathrm{H}$ NMR ( $\mathrm{CD}_{3} \mathrm{OD}, 295 \mathrm{~K}, \delta \mathrm{ppm}, J \mathrm{~Hz}$ ): 9.8 (dd, 2H, $\mathrm{H}^{6,6^{\prime}}$ bpm, J 1.96, J 5.76); 9.28 (dd, $2 \mathrm{H}$, $\mathrm{H}^{4,4^{\prime}}{ }_{\text {bpm }}, J 1.96, J$ 4.77); $7.96\left(\mathrm{t}, 2 \mathrm{H}, \mathrm{H}^{5,5^{\prime}}\right.$ bpm, J 5.26); 6.22 (d, 2H, $\left.\mathrm{Ar}_{p-c y}, J 6.43\right) ; 6.01$ (d, 2H, $\mathrm{Ar}_{p-c y}, J$ 6.43); 2.79 (sep, $\left.1 \mathrm{H},-\mathrm{C} \underline{\mathrm{H}}\left(\mathrm{CH}_{3}\right)_{2 p-c y}\right) ; 2.25\left(\mathrm{~s}, 3 \mathrm{H}, \mathrm{CH}_{3 p-c y}\right) ; 1.17\left(\mathrm{~d}, 6 \mathrm{H},-\mathrm{CH}\left(\mathrm{CH}_{3}\right)_{2 p-c y}, \quad 6.91\right)$, Analysis found: $\mathrm{C}, 43.61 \% ; \mathrm{H}, 4.89 \% ; \mathrm{N}, 11.40 \%$. Calculated: $\mathrm{C}, 43.97 \% ; \mathrm{H}, 4.71 \% ; \mathrm{N}, 11.39 \%$ for $\mathrm{C}_{18} \mathrm{H}_{20} \mathrm{~N}_{4} \mathrm{Ru}_{1} \mathrm{Cl}_{2} \cdot 1.5 \mathrm{H}_{2} \mathrm{O}$ complex.

\section{[RuII(cy)(mbpy)Cl]}

The orange-yellow chloro complex $\left[\mathrm{Ru}^{\prime \prime}(\mathrm{cy})(\mathrm{mbpy}) \mathrm{Cl}\right]^{+}$was prepared in a similar manner as described for [Ru'(cy)(bpy)Cl] ${ }^{+}$using 4,4'-dimethyl-2,2'-bipyridine (dmbpy: $0.184 \mathrm{~g}, 1.0 \mathrm{mmol}$ ) instead of 2,2'bipyridine. Yield $0.37 \mathrm{~g}, 76 \% .{ }^{1} \mathrm{H}$ NMR ( $\left.\mathrm{CD}_{3} \mathrm{OD}, 295 \mathrm{~K}, \delta \mathrm{ppm}, J \mathrm{~Hz}\right): 9.26\left(\mathrm{~d}, 2 \mathrm{H}, \mathrm{H}^{6,6^{\prime}}{ }_{\text {mbpy }}, J 5.85\right) ; 8.37$ $\left(\mathrm{s}, 2 \mathrm{H}, \mathrm{H}^{3,3^{\prime}}\right.$ mbpy $) ; 7.58\left(\mathrm{~d}, 2 \mathrm{H}, \mathrm{H}^{5,5^{\prime}}{ }_{\text {mbpy }}, J 5.85\right) ; 2.62\left(\mathrm{~s}, 6 \mathrm{H}, 4,4^{\prime}-\left(\mathrm{CH}_{3}\right)_{2}\right.$ mbpy); 6.06 (d, 2H, $\left.\mathrm{Ar}_{p-c y}, J 6.33\right)$; 5.80 (d, 2H, $\left.\mathrm{Ar}_{p-c y}, J 6.33\right) ; 2.60$ (sep, $\left.1 \mathrm{H},-\mathrm{C} \underline{\mathrm{H}}\left(\mathrm{CH}_{3}\right)_{2 p-c y}\right) ; 2.26$ (s, 3H, $\left.\mathrm{CH}_{3 p-c y}\right) ; 1.03$ (d, 6H, $-\mathrm{CH}\left(\mathrm{CH}_{3}\right)_{2 p-}$ cy, J 6.91), Analysis found: C, 51.20\%; H, 5.96\%; N, 5.53\%. Calculated: C, 51.97\%; H, 5.55\%; N, 5.51\% for $\mathrm{C}_{22} \mathrm{H}_{26} \mathrm{~N}_{2} \mathrm{Ru}_{1} \mathrm{Cl}_{2} \cdot \mathrm{H}_{2} \mathrm{O}$ complex. 


\section{Calculated multiplicity proposed intermediates}

Table S2. Determination of the most energetically stable multiplicity for each of the catalytic intermediates of Ru-bpc. $\Delta E$ is the energy relative to the lowest energy multiplicity for that intermediate (indicated by asterisks). $\Delta S^{2}$ is here defined as the difference between the exact and expected value for $S^{2}$, which can be considered an indication of the level of spin contamination for that multiplicity. ${ }^{1}$

\begin{tabular}{|c|c|c|c|c|c|c|c|}
\hline & \multicolumn{3}{|c|}{ B3LYP } & \multicolumn{3}{|c|}{ OPBE } \\
\hline & & $\begin{array}{l}\Delta E \\
(\mathrm{eV})\end{array}$ & $\begin{array}{c}\Delta E \\
\text { (kcal/mol) }\end{array}$ & $\Delta S^{2}$ & $\begin{array}{c}\Delta E \\
(\mathrm{eV})\end{array}$ & $\begin{array}{c}\Delta E \\
\text { (kcal/mol) }\end{array}$ & $\Delta S^{2}$ \\
\hline \multirow[t]{3}{*}[\mathrm{Ru}^{\mathrm{II}}-\mathrm{OH}_{2}]{$^{2+}$} & *singlet* & 0.00 & 0.00 & 0.00 & 0.00 & 0.00 & 0.00 \\
\hline & triplet & 1.29 & 29.85 & 0.01 & 1.60 & 36.79 & 0.01 \\
\hline & quintet & 1.86 & 42.94 & 0.01 & 2.75 & 63.36 & 0.02 \\
\hline \multirow[t]{3}{*}[\mathrm{Ru}^{\prime\prime\prime}-\mathrm{OH}]{$^{2+}$} & *doublet* & 0.00 & 0.00 & 0.01 & 0.00 & 0.00 & 0.00 \\
\hline & quartet & 1.36 & 31.33 & 0.02 & 1.62 & 37.29 & 0.02 \\
\hline & sextet & 2.11 & 48.59 & 0.01 & 4.28 & 98.64 & 0.03 \\
\hline \multirow[t]{3}{*}[Ru^{IV}=O]{$^{2+}$} & singlet & 0.27 & 6.31 & 0.95 & 0.25 & 5.67 & 0.89 \\
\hline & $*$ triplet* & 0.00 & 0.00 & 0.01 & 0.00 & 0.00 & 0.01 \\
\hline & quintet & 1.22 & 28.24 & 0.02 & 1.65 & 38.07 & 0.01 \\
\hline \multirow[t]{3}{*}[\mathrm{Ru}^{\mathrm{III}}-\mathrm{OOH}]{$^{2+}$} & *doublet* & 0.00 & 0.00 & 0.01 & 0.00 & 0.00 & 0.00 \\
\hline & quartet & 1.33 & 30.78 & 0.02 & 1.63 & 37.53 & 0.02 \\
\hline & sextet & 2.06 & 47.62 & 0.01 & 2.86 & 65.91 & 0.01 \\
\hline \multirow{4}{*}[\mathrm{Ru}^{\prime\prime}-\mathrm{OO}]{$^{2+}$} & singlet & 0.22 & 5.13 & 0.00 & 0.06 & 1.49 & 0.00 \\
\hline & *triplet* & 0.00 & 0.00 & 0.01 & 0.00 & 0.00 & 0.01 \\
\hline & quintet & 0.96 & 22.10 & 0.02 & 1.16 & 26.70 & 0.02 \\
\hline & septet & 1.95 & 45.06 & 0.02 & 2.60 & 59.95 & 0.02 \\
\hline
\end{tabular}




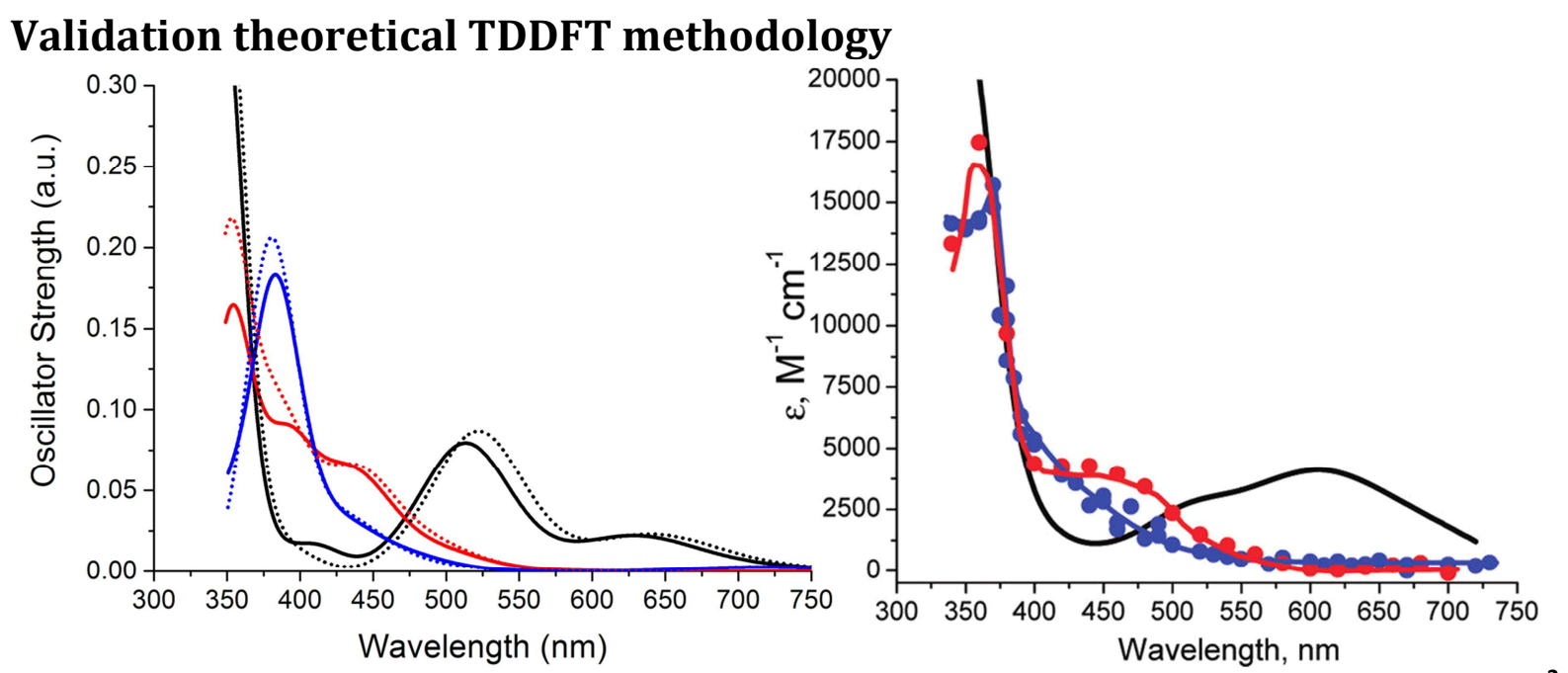

Figure S1. Calculated TDDFT spectra (left) of the Ru-based WOC investigated by Polyanski et al, ${ }^{2}$ with $\left[\mathrm{Ru}^{\mathrm{II}}-\mathrm{OH}_{2}\right]^{2+}$ in black, $\left[\mathrm{Ru}{ }^{\mathrm{III}}-\mathrm{OH}\right]^{2+}$ in red and $\left[\mathrm{Ru}^{\mathrm{IV}}=\mathrm{O}\right]^{2+}$ in blue. The dotted lines indicate the calculations done with the larger basis set. These calculated curves have a Gaussian broadening of $0.3 \mathrm{eV}$. The experimental data is reproduced at right from Polyansky, D. E.; Muckerman, J. T.; et al. J. Am. Chem. Soc. 2011, 133 (37), 14649.

The computational set-up employed for the TDDFT calculations in this work (B3LYP/TZP/COSMO) is tested using a benchmark ruthenium-based WOC, for which experimental data is available for comparison. ${ }^{2}$ Further calculations were also performed with the larger QZ4P basis set for Ru and TZ2P for $\mathrm{H}, \mathrm{C}, \mathrm{N}, \mathrm{O}$. The calculated results (Figure S1) show a close agreement with the published experimental data, ${ }^{2}$ though the intensities of the peaks around $525 \mathrm{~nm}$ and $625 \mathrm{~nm}$ are interchanged. Furthermore, using the larger basis sets does not significantly affect the key features. A summary of the key features is given in Table S3. The computed spectra validate the ability of this method to accurately reproduce the optical properties of compounds chemically similar to the WOC of interest for this study.

Table S3. Primary excitations for the intermediates of the benchmark catalyst calculated using TDDFT, as compared to experiment performed by Polyanski et al. ${ }^{2}$

\begin{tabular}{cllccc}
\hline & & \multicolumn{2}{c}{ Wavelength (nm) } & \multicolumn{2}{c}{ Energy (eV) } \\
& & Exp & Calc & Exp & Calc \\
\hline$\left[\mathrm{Ru}^{\mathrm{II}}-\mathrm{OH}_{2}\right]^{2+}$ & $\lambda_{\max }$ & 605 & 630 & 2.05 & 1.97 \\
& $\lambda_{\text {shoulder }}$ & 520 & 515 & 2.38 & 2.41 \\
{$\left[\mathrm{Ru}^{\mathrm{III}}-\mathrm{OH}\right]^{2+}$} & $\lambda_{\max }$ & 360 & 355 & 3.44 & 3.49 \\
& $\lambda_{\text {shoulder }}$ & 450 & 430 & 2.76 & 2.88 \\
{$\left[\mathrm{Ru}^{\mathrm{IV}}=\mathrm{O}\right]^{2+}$} & $\lambda_{\max }$ & 370 & 380 & 3.35 & 3.26 \\
& $\lambda_{\text {onset }}$ & 500 & 500 & 2.48 & 2.48 \\
\hline
\end{tabular}




\section{Cyclic Voltammetry measurements}

Electrochemical investigations and cyclic voltammetry (CV) were performed with an Autolab PGstat10 potentiostat controlled by GPES-4 software at a scan rate of $50 \mathrm{mV} / \mathrm{sec}$. A three electrode configuration pyrex glass cell was employed for electrochemical studies containing aqueous solutions of the catalysts $(2.5 \mathrm{mM})$. Solutions were prepared in ultra-pure water and electrochemical measurements were performed in deoxygenated aqueous solutions at room temperature.

The working electrode (WE) in the CV experiments was a freshly polished glassy carbon (GC) disk $(\mathrm{d}=5.0 \mathrm{~mm}$ ), embedded in a PTFE shroud. A mirror finishing was achieved by polishing the GC disk mechanically with an aqueous slurry of $0.3,0.1$ and $0.05 \mu \mathrm{m}$ alumina (Buehler Limited) successively, on a microcloth polishing fabric. Platinum wire (thickness $\mathrm{I}=1 \mathrm{~mm}$ ), shaped into a spiral, was used as a counter electrode (CE). A mercury-mercury sulfate electrode (MMSE: $\mathrm{Hg} / \mathrm{Hg}_{2} \mathrm{SO}_{4} / \mathrm{K}_{2} \mathrm{SO}_{4}$ ) was used as a reference electrode (RE) for the measurements in aqueous solution $(\mathrm{pH}<6)$ and a silver-silver chloride electrode (SSCE: $\mathrm{Ag} / \mathrm{AgCl} / \mathrm{KCl}$ ) was applied for the investigations in the neutral and higher $\mathrm{pH}$ aqueous solutions. All potentials are referred to the normal hydrogen electrode (NHE).
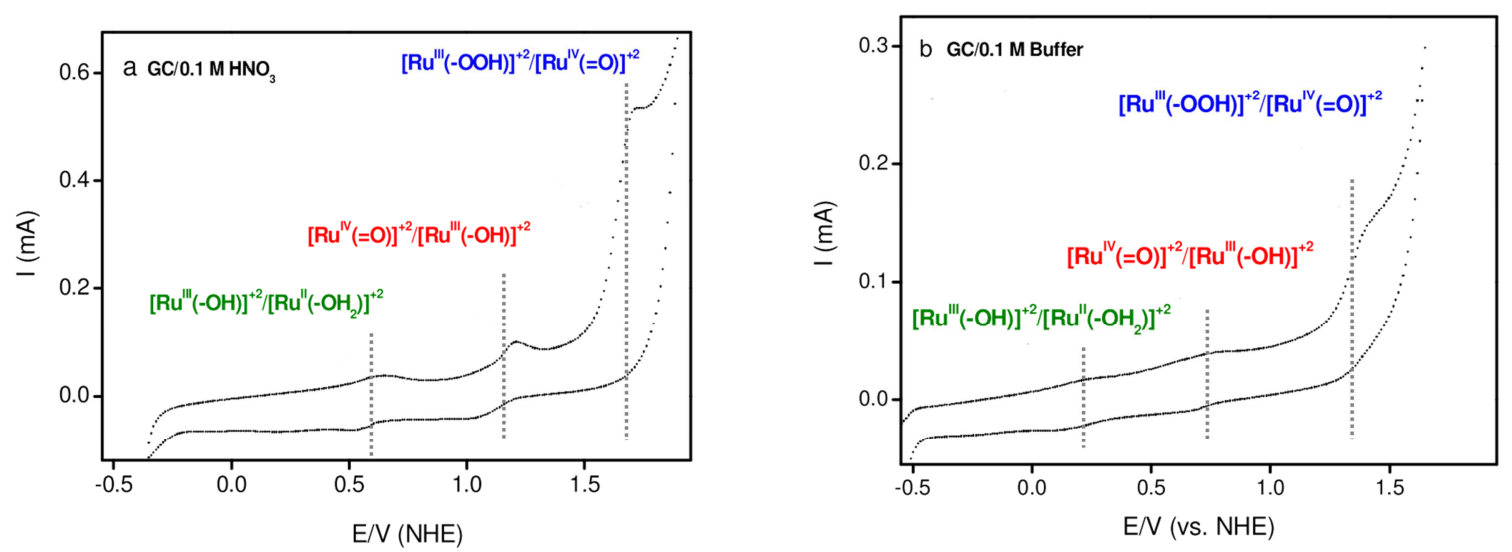

Figure S2. Cyclic voltammogram of $R u$-bpc $(2 \mathrm{mM})$ at glassy carbon disk working electrode in $0.1 \mathrm{M}$ (a) $\mathrm{HNO}_{3}$ and (b) buffer (pH 7.35) solutions showing $\left[\mathrm{Ru}^{\prime \prime \prime}-\mathrm{OH}\right]^{2+} /\left[\mathrm{Ru}^{\prime \prime}-\mathrm{OH}_{2}\right]^{2+}$ and $\left[\mathrm{Ru}^{\mathrm{IV}}=0\right]^{2+} /\left[\mathrm{Ru}^{\mathrm{III}}-\mathrm{OH}\right]^{2+}$ reversible couples. Scan rate was $100 \mathrm{mV} / \mathrm{sec}$ and glassy carbon disk was $5 \mathrm{~mm}$ diameter.
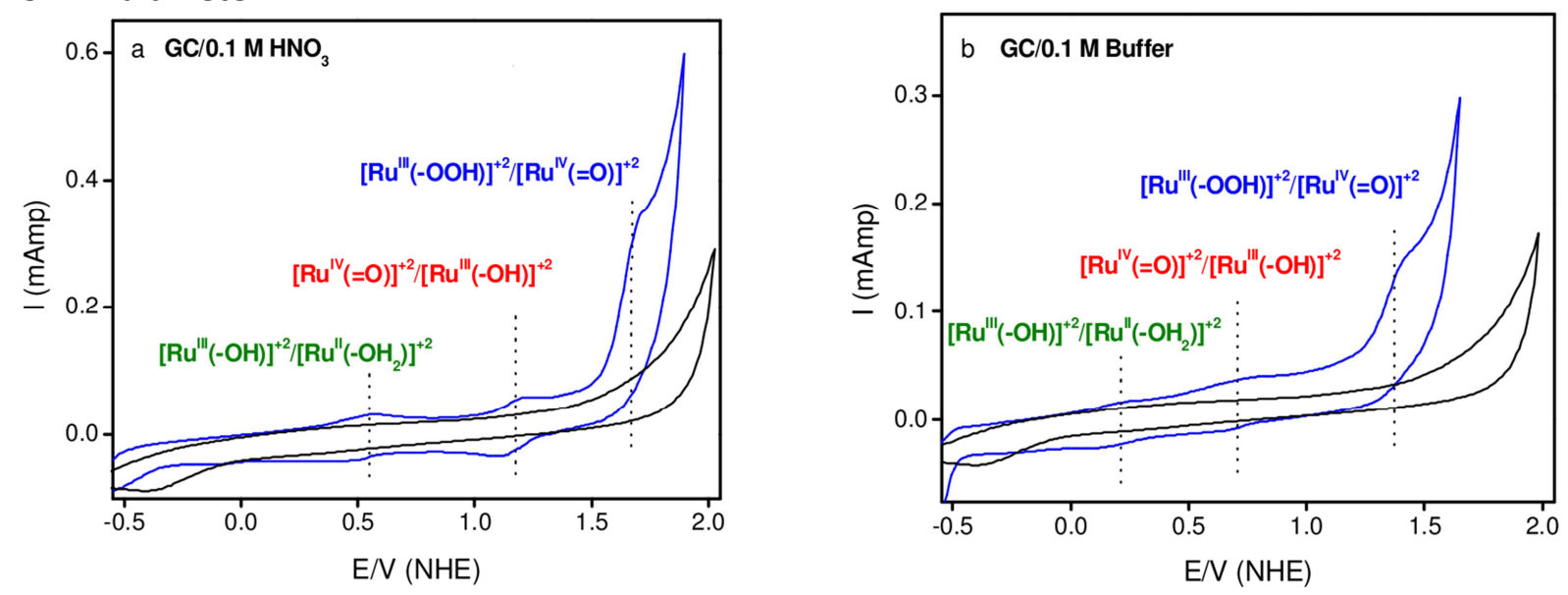

Figure S3. Cyclic voltammogram of Ru-bpy $(2.5 \mathrm{mM})$ at glassy carbon disk working electrode in 0.1 $M$ (a) $\mathrm{HNO}_{3}$ and (b) buffer (pH 7.35) solutions showing $[\mathrm{Ru} \text { "'-OH] }]^{2+} /\left[\mathrm{Ru}^{\prime \prime}-\mathrm{OH}_{2}\right]^{2+}$ and $\left[\mathrm{Ru}^{\mathrm{IV}}=0\right]^{2+} /\left[\mathrm{Ru}^{\mathrm{III}}-\mathrm{OH}\right]^{2+}$ reversible couples. Scan rate was $100 \mathrm{mV} / \mathrm{sec}$ and glassy carbon disk was $5 \mathrm{~mm}$ diameter. 


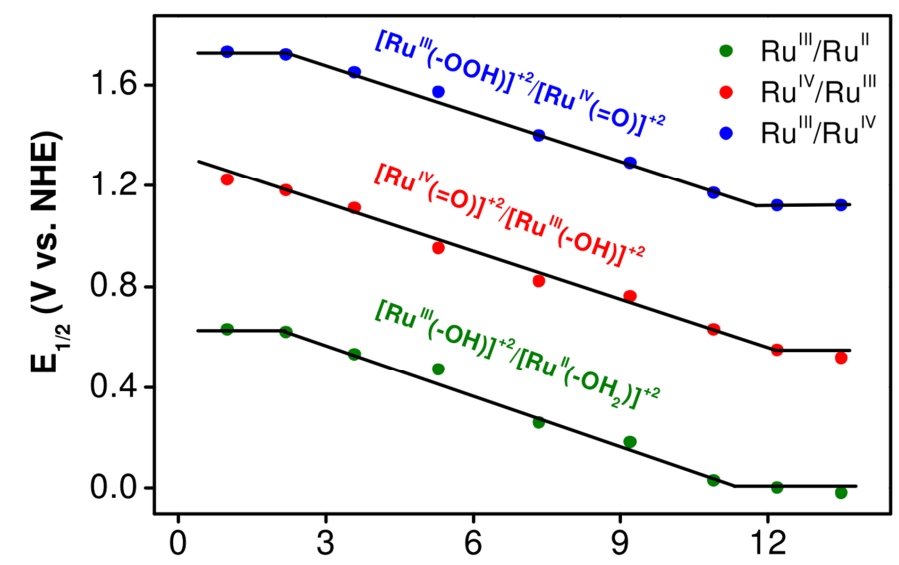

Figure S4. Potential vs pH plot (Pourbaix diagram) for the $\left[\mathrm{Ru}^{\mathrm{III}}-\mathrm{OH}\right]^{2+} /\left[\mathrm{Ru}^{\mathrm{I}}-\mathrm{OH}_{2}\right]^{2+}$, $\left[\mathrm{Ru}^{\mathrm{IV}}=0\right]^{2+} /\left[\mathrm{Ru}^{\mathrm{III}}-\mathrm{OH}\right]^{2+}$ and $\left[\mathrm{Ru}^{\mathrm{III}}-\mathrm{OOH}\right]^{2+} /\left[\mathrm{Ru}^{\mathrm{IV}}=0\right]^{2+}$ couples for $\mathrm{Ru}$-bpc at a glassy carbon disk (5 $\mathrm{mm}$ diameter) working electrode in $0.1 \mathrm{M}$ aqueous solutions.

\section{Raman frequency calculations}
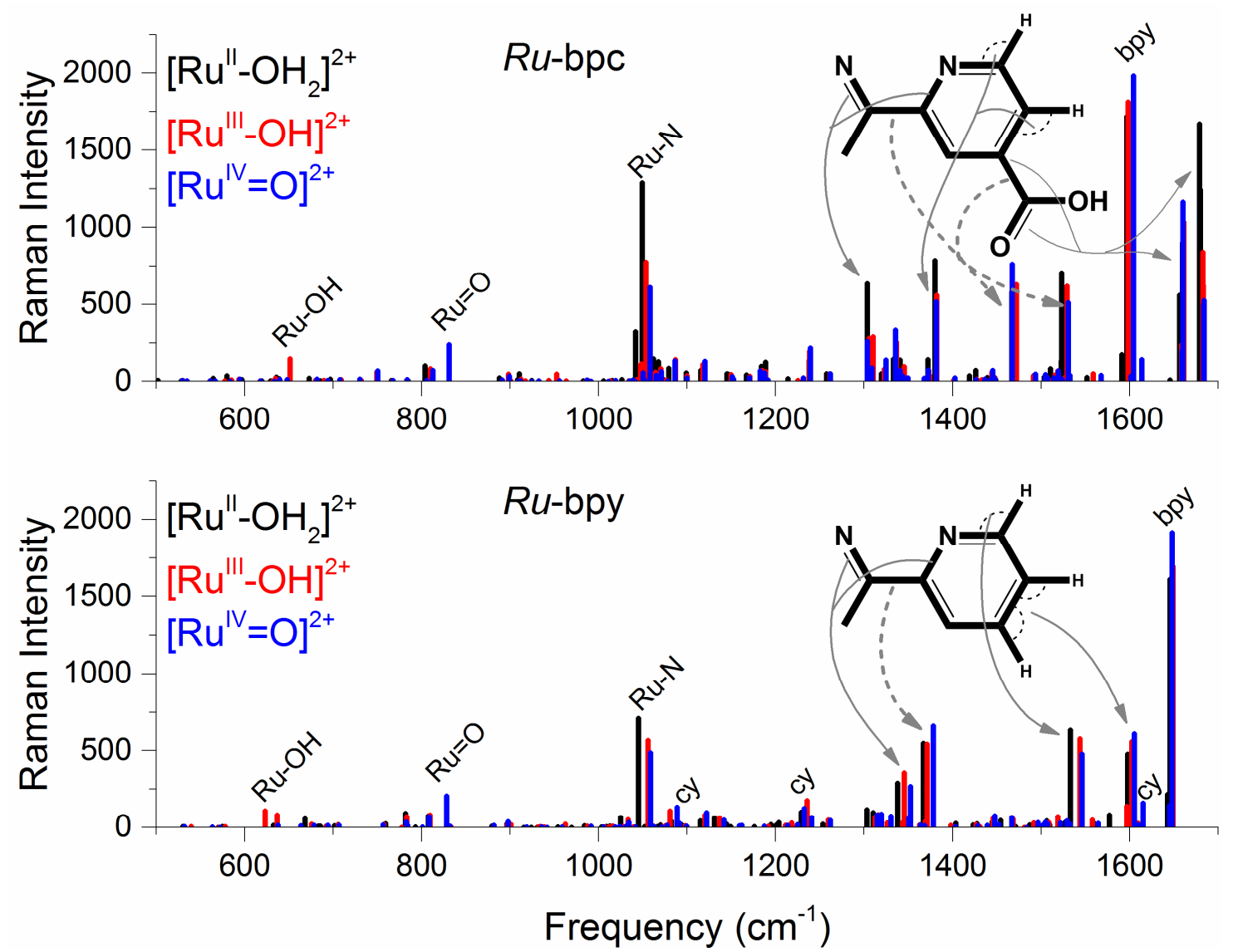

Figure S5. Raman frequency calculations of $\left[\mathrm{Ru}^{\mathrm{II}}-\mathrm{OH}_{2}\right]^{2+},\left[\mathrm{Ru} \mathrm{u}^{\mathrm{III}}-\mathrm{OH}\right]^{2+}$ and $\left[\mathrm{Ru}^{\mathrm{IV}}=\mathrm{O}\right]^{2+}$ as calculated for $R u$-bpc and Ru-bpy. Annotations show the nature of each mode. 


\section{Time-dependent UV-Vis absorption of CeIV}

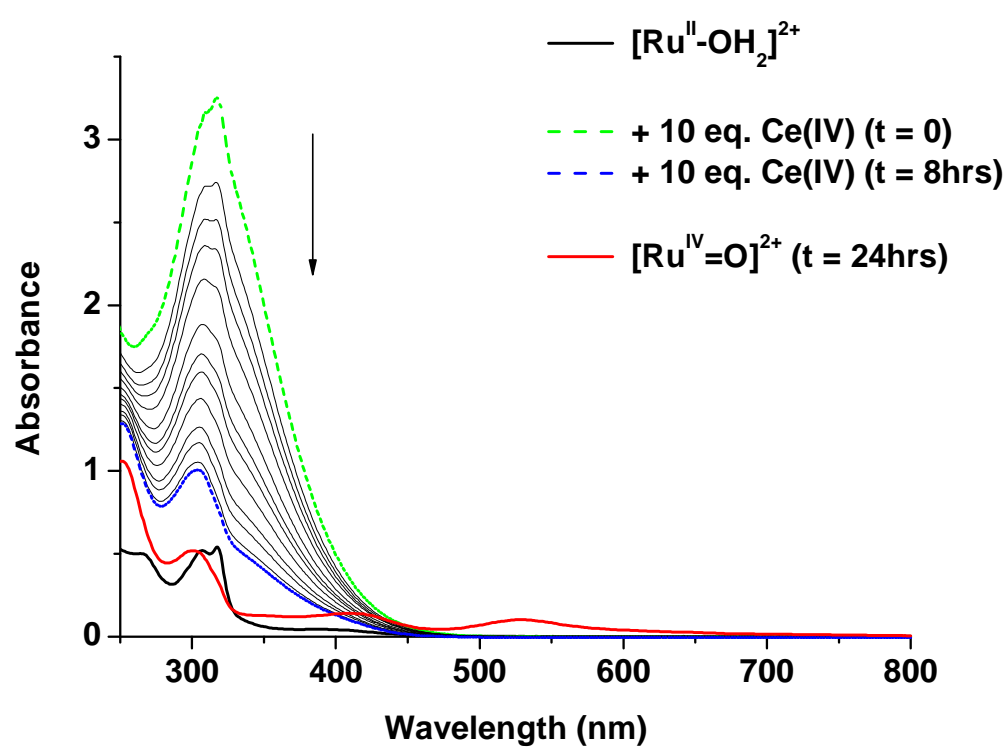

Figure S6. Spectral evolution of Ru-bpy upon addition of 10 equivalents of $\mathrm{CAN}$ in $\mathrm{H}_{2} \mathrm{SO}_{4} \mathbf{1 N}$. Black curve is the spectrum of the Ru complex (c=5x10-5 M) before mixing; red curve is the spectrum of the oxidized species, [Ru $\left.\mathrm{R}^{\mathrm{IV}}=0\right]^{2+}$, obtained after 24 hours upon addition of CAN. 


\section{Calculated absorption spectra entire cycle $R u$-bpy}

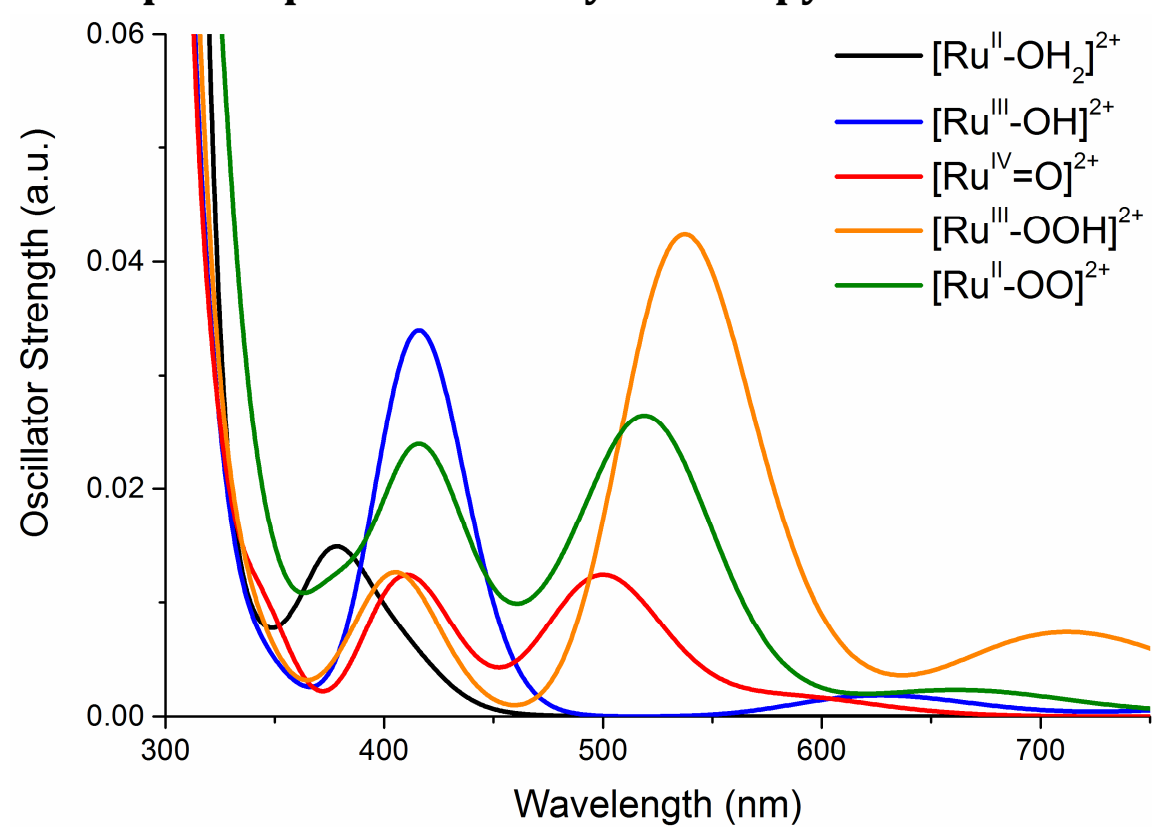

Figure S7. TDDFT computed spectra of the entire catalytic cycle of Ru-bpy.

These calculations may be used to verify the existence of $R u$-bpy catalytic intermediates when compared to experimental absorption spectra. The characteristic peak at $500 \mathrm{~nm}$ in the $\left[\mathrm{Ru}^{\mathrm{IV}}=0\right]^{2+}$ spectrum is due to one excitation (shown in Figure S8), whereas most of the other peaks originate from a mixture of different orbital transitions. It is of note that the catalytic intermediates share a peak around $410 \mathrm{~nm}$ (with $\left[\mathrm{Ru}^{\mathrm{III}}-\mathrm{OH}\right]^{2+}$ and $\left[\mathrm{Ru} \mathrm{u}^{\mathrm{III}}-\mathrm{OOH}\right]^{2+}$, and $\left[\mathrm{Ru}^{\mathrm{IV}}=\mathrm{O}\right]^{2+}$ and $\left[\mathrm{Ru}^{\mathrm{IV}}-\mathrm{OOO}\right]^{2+}$ being relatively similar) while the only peak in the $\left[\mathrm{Ru}^{\prime \prime}-\mathrm{OH}_{2}\right]^{2+}$ spectrum is slightly higher in energy. That the peak in the $\left[\mathrm{Ru}^{\prime \prime}-\mathrm{OH}_{2}\right]^{2+}$ spectrum is higher in energy is likely due to the doubly occupied nature of all the occupied valence $d$ orbitals of ruthenium. Comparatively, the other catalytic intermediates have singly occupied $d$ orbitals, which leads to the corresponding unoccupied d orbitals forming low lying unoccupied states

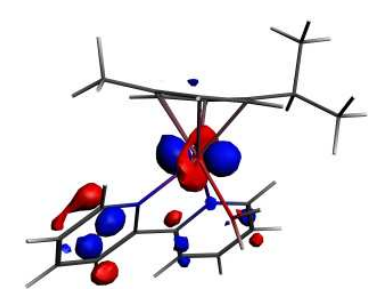

HOMO-2

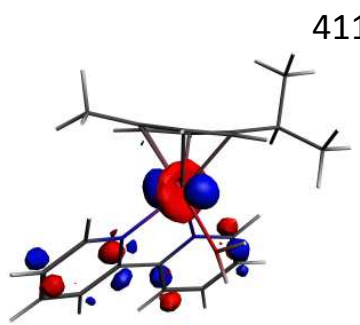

HOMO-1

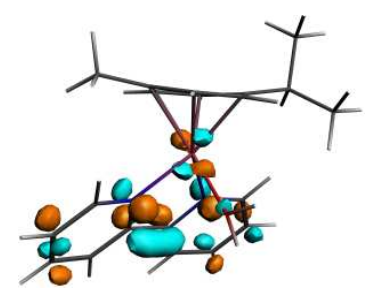

LUMO

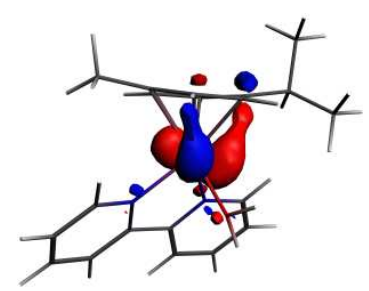

HOMO

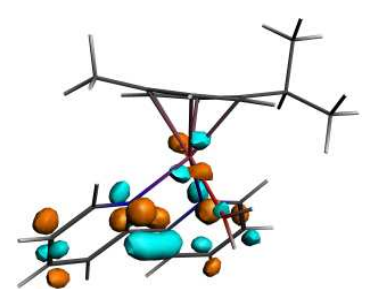

LUMO

$391 \mathrm{~nm}$

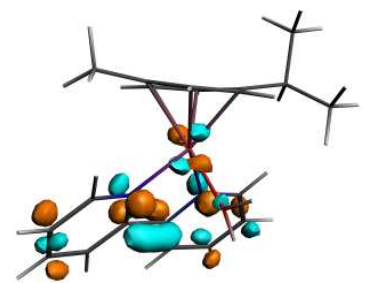

LUMO

$375 \mathrm{~nm}$

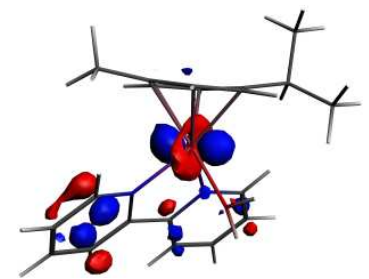

HOMO-2

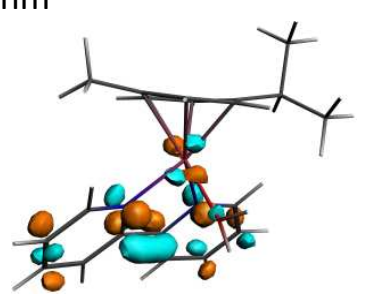

LUMO

$303 \mathrm{~nm}$

Figure S8. Molecular orbitals involved in the excitations calculated for the $\left[\mathrm{Ru}^{\prime \prime}-\mathrm{OH}_{2}\right]^{2+}$ catalytic intermediate of Ru-bpy. 
Orbital comparison of $\left[\mathrm{Ru}^{\mathrm{IV}}=0\right]^{2+}$ intermediates

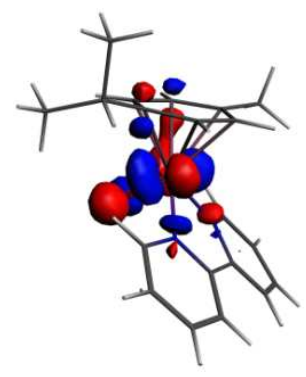

HOMO $\alpha$

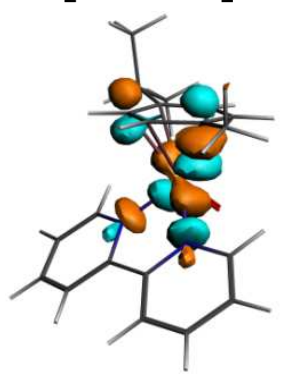

$\operatorname{LUMO} \alpha$

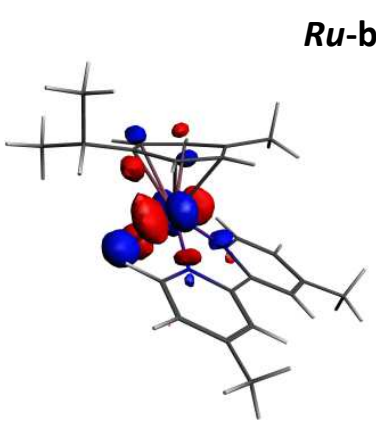

$\operatorname{HOMO} \alpha$

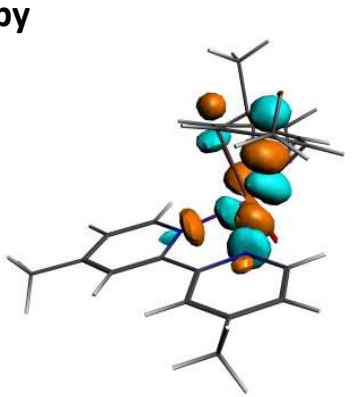

$\operatorname{LUMO} \alpha$

Ru-mbpy

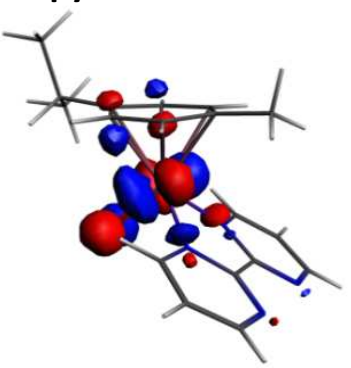

HOMO $\alpha$

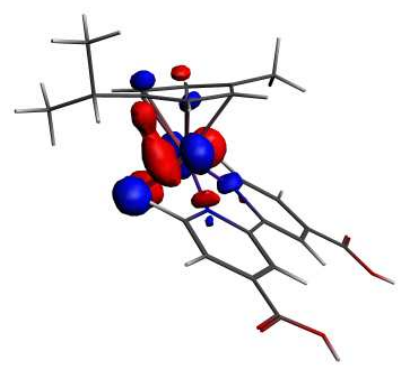

HOMO $\alpha$

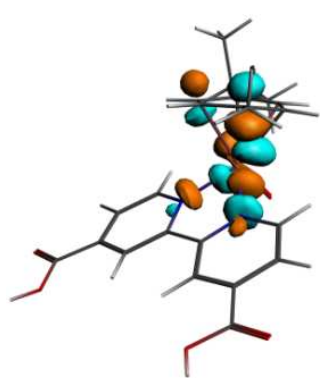

$L U M O+1 \alpha$

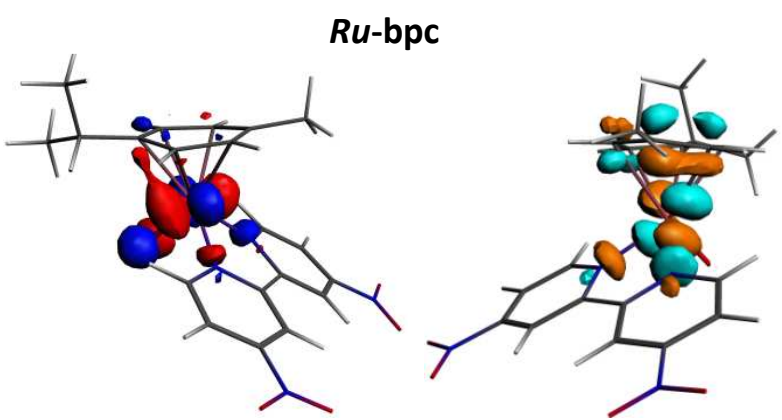

HOMO $\alpha$

$L U M O+2 \alpha$

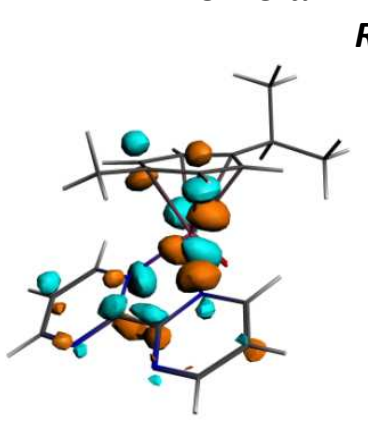

$\operatorname{LUMO} \alpha$

Ru-bpm

Figure S9. Molecular orbitals involved in the signature excitation around $500 \mathrm{~nm}$ for the $\left[\mathrm{Ru}^{\mathrm{IV}}=0\right]^{2+}$ catalytic intermediate of the different derivative catalysts. 
UV-Vis absorption data for $\left[\mathrm{Ru}^{\mathrm{II}}-\mathrm{OH}_{2}\right]^{2+}$ complexes

Table S4. Absorption properties of the catalysts in their aqua-form in $\mathrm{H}_{2} \mathrm{SO}_{4} \mathbf{1 N}$ solution.

\begin{tabular}{ll}
\hline & $\lambda \mathrm{nm}, \varepsilon \mathrm{M}^{-1} \mathrm{~cm}^{-1}$ \\
\hline$R u$-bpy & $246(10800), 307(10400), 317(10800), 400(800)$ \\
$R u$-bpc & $286(13400), 323(12100), 335(13000), 400(2100)$ \\
$R u$-bpm & $250(15500), 400(1400)$ \\
$R u$-bpn & $319(12200), 400(3400)$ \\
$R u$-phen & $278(23400), 302 \mathrm{sh}(8400), 400(800)$ \\
$R u$-mbpy & $263(12300), 304(10900), 314(11100), 400(900)$ \\
\hline
\end{tabular}

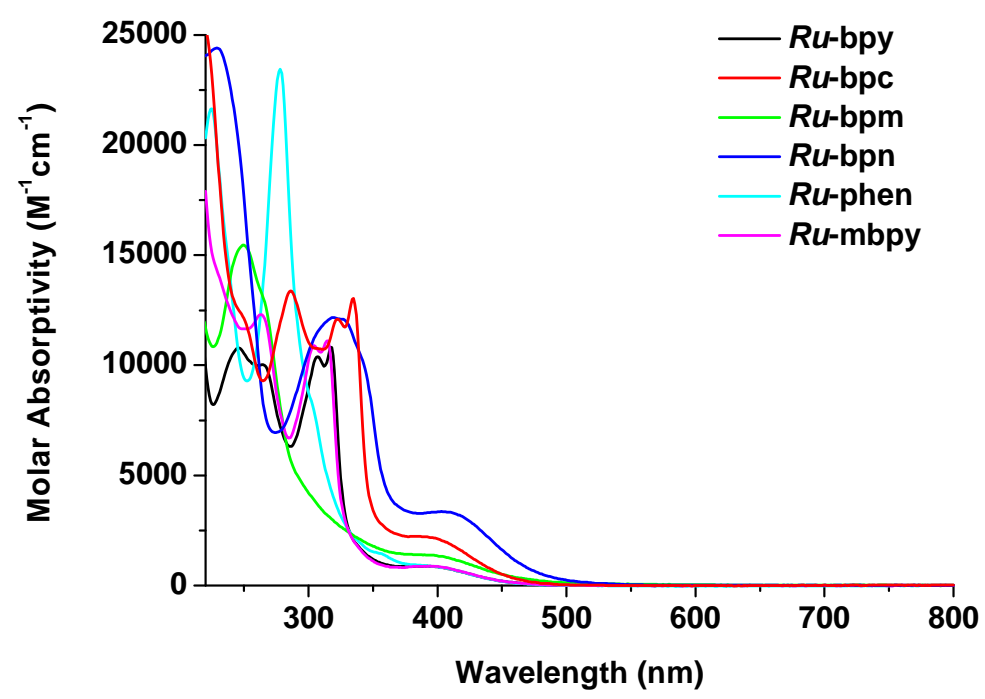

Figure S10. Absorption spectra of the catalysts in their aqua-form in $\mathrm{H}_{2} \mathrm{SO}_{4} 1 \mathrm{~N}$ solution 


\section{Elucidation [RuIII-OH $]^{2+}$}

\section{Pulse radiolysis in basic solution}

The reactivity of $R u$-bpy with $\mathrm{CO}_{3}{ }^{--}$was determined by following the decay of the carbonate radical absorption at $600 \mathrm{~nm}$ in the presence of increasing concentrations of the substrate. The natural decay of $\mathrm{CO}_{3}{ }^{--}$follows second order kinetics in the absence of any reducing moieties. When the radical reacts with a target, the pulse radiolysis kinetics become first order reactions whose observed rate constants increase with increasing concentration of the reducing moiety.

By using $\mathrm{Na}_{2} \mathrm{CO}_{3} / \mathrm{NaHCO}_{3}(5 \mathrm{mM}: 5 \mathrm{mM})(\mathrm{pH}=10)$ the $\mathrm{pH}$ of the solution is too high to observe the absorption of the oxidized forms of Ru-bpy, because they decompose too fast to be observed, i.e. below the time resolution of our apparatus (rise-time $~ 2.5 \mathrm{~ns}$ ).

The spectra in Figure S11 can be attributed to the $\mathrm{CO}_{3}{ }^{-{ }^{-}}$decay, with some evidence for $\mathrm{Ru}$-bpy transient formation in the region 250-350 nm. From these experiments it was possible to determine the rate constant for the reaction of $\mathrm{Ru}$-bpy with $\mathrm{CO}_{3}{ }^{-{ }^{-}}$by following the first order decay at $600 \mathrm{~nm}$ : the value obtained is $k\left(\mathrm{CO}_{3}{ }^{--}+R u-b p y\right)=(3.0 \pm 0.3) \times 10^{7} \mathrm{M}^{-1} \mathrm{~s}^{-1}$.

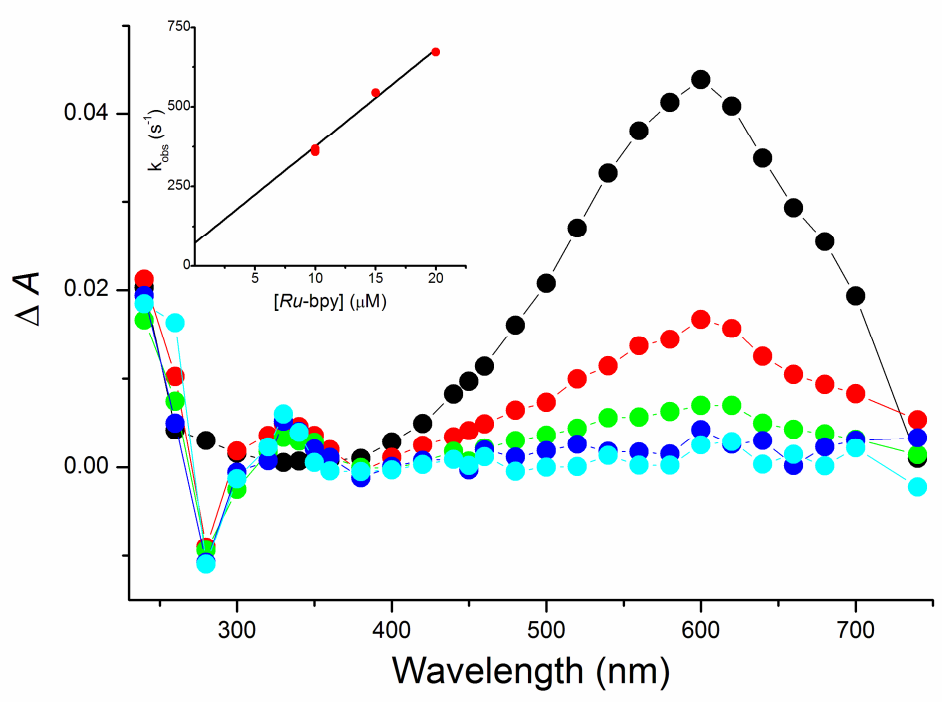

Figure S11. Transient absorption spectra obtained by $\mathrm{CO}_{3}{ }^{--}$radical oxidation of $R u$-bpy (c $=10 \mu \mathrm{M}$ ) after pulse radiolysis of $\mathrm{N}_{2} \mathrm{O}$-saturated solution containing $\mathrm{Na}_{2} \mathrm{CO}_{3} / \mathrm{NaHCO}_{3}(5 \mathrm{mM}: 5 \mathrm{mM}$ ) at pH 10: (black) $200 \mu \mathrm{s}$, (red) $2 \mathrm{~ms}$, (green) $6 \mathrm{~ms}$, (blue) $10 \mathrm{~ms}$ and (cyan) $17 \mathrm{~ms}$ after the pulse. Optical path $=\mathbf{2} \mathrm{cm}$, dose per pulse $=\mathbf{2 2 . 2} \mathrm{Gy}$. Inset: Plot of $\mathrm{k}_{\mathrm{obs}} \mathrm{vs}$ [Ru-bpy] molar concentration (red dots) for the decay of the main signal at $600 \mathrm{~nm}$ after pulse radiolysis of Ru-bpy in $\mathrm{N}_{2} \mathrm{O}$-saturated solution containing $\mathrm{Na}_{2} \mathrm{CO}_{3} / \mathrm{NaHCO}_{3}(5 \mathrm{mM}: 5 \mathrm{mM}$ ) at pH 10. Optical path $=2 \mathrm{~cm}$, dose per pulse 44.4 Gy; solid line represents the linear regression fit to the data. 


\section{Pulse radiolysis in acidic solution}

When $\mathrm{SO}_{4}{ }^{-}$is produced in acidic solution, in the absence of any reducing species, the transient spectra show the same behaviour observed at neutral $\mathrm{pH}$ with a lower extinction coefficient, $\varepsilon$. The resulting $\varepsilon$ is three times smaller than that reported in the literature at $\mathrm{pH}=5.1\left(\varepsilon=361 \mathrm{M}^{-1} \mathrm{~cm}^{-1}\right.$

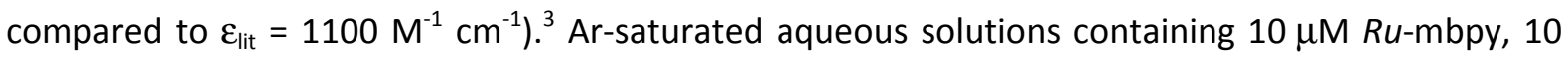
$\mathrm{mM} \mathrm{K}_{2} \mathrm{~S}_{2} \mathrm{O}_{8}$ and $0.1 \mathrm{M} \mathrm{t}$ - $\mathrm{BuOH}$ were pulse-irradiated at $\mathrm{pH}=1.4$ at two different doses, 38 and $82 \mathrm{~Gy}$. From the $\mathrm{SO}_{4}{ }^{-}$extinction coefficient $\varepsilon$ obtained at acidic $\mathrm{pH}$, we can assume that $\sim 33 \%$ of $\mathrm{e}_{\mathrm{aq}}{ }^{-}$ generates $\mathrm{SO}_{4}{ }^{-}$(eq. R1) with a concentration of $3.4 \mu \mathrm{M}$ when the dose was $38 \mathrm{~Gy}$ (see Figure 7) and $7.3 \mu \mathrm{M}$ when the dose was $80 \mathrm{~Gy}$ (see Figure S12). The remaining hydrated electron reacts with $\mathrm{H}_{3} \mathrm{O}^{+}$ (eq. $\left.\mathrm{R} 2, k_{4}=2.3 \times 10^{10} \mathrm{M}^{-1} \mathrm{~s}^{-1}\right)^{4}$ giving the $\mathrm{H}^{\bullet}$ transient species.

$\mathrm{e}_{\mathrm{aq}}{ }^{-}+\mathrm{S}_{2} \mathrm{O}_{8}{ }^{2-} \rightarrow \mathrm{SO}_{4}{ }^{--}+\mathrm{SO}_{4}{ }^{2-}$

$\mathrm{e}_{\mathrm{aq}}{ }^{-}+\mathrm{H}_{3} \mathrm{O}^{+} \rightarrow \mathrm{H}^{\cdot}+\mathrm{H}_{2} \mathrm{O}$

$\mathrm{H}^{\bullet}$ can react with $\mathrm{S}_{2} \mathrm{O}_{8}{ }^{2-}$ to produce the $\mathrm{HSO}_{4}{ }^{*}$ radical, ${ }^{5}$ a species whose standard redox potential is not reported in literature, but is able to oxidize moieties similar to $R u$-mbpy. A photochemical study on the reaction between $\mathrm{SO}_{4}{ }^{--}$and $\left[\mathrm{Ru}(\mathrm{bpy})_{3}\right]^{2+}$ at acidic $\mathrm{pH}$ showed that oxidation occurs, though with a lower rate constant with respect to that already reported by Yamada and Hurst. ${ }^{6}$ The contribution of $\mathrm{HSO}_{4}{ }^{\circ}$ to the oxidation of $\mathrm{Ru}$-mbpy must be considered since the yield of oxidant species, i.e. $33 \%$, is higher than expected from the only $\mathrm{SO}_{4}{ }^{--}$reaction. It was not experimentally possible to achieve a higher concentration of oxidizer or to apply a higher dose to achieve $100 \%$ conversion of $\mathrm{e}_{\mathrm{aq}}{ }^{-}$to $\mathrm{SO}_{4}{ }^{--}$.

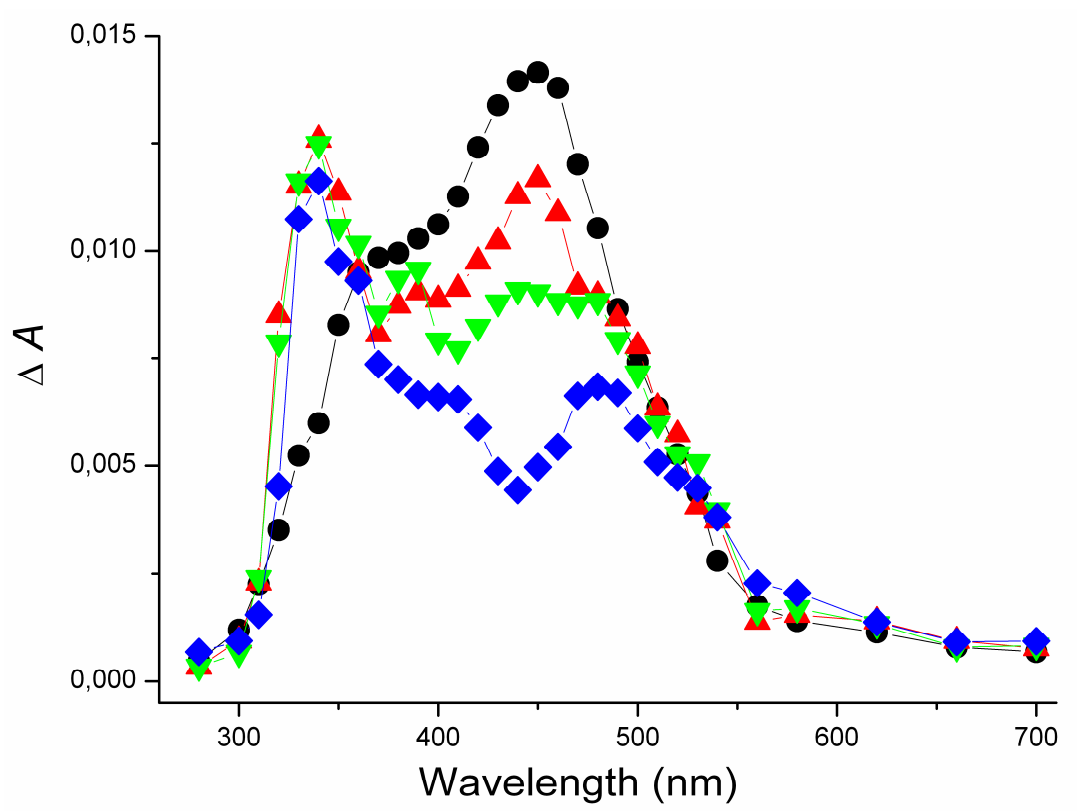

Figure S12. Transient absorption spectra obtained by $\mathrm{SO}_{4}{ }^{\circ-}$ radical oxidation of $\mathrm{Ru}$-mbpy (c $=10^{-5}$ M) after pulse radiolysis of Argon purged solution containing $10 \mathrm{mM} \mathrm{K} \mathrm{S}_{2} \mathrm{O}_{8}$ and $0.1 \mathrm{M} \mathrm{t}$-BuOH at pH 1.3: (black) $1.5 \mu \mathrm{s}$, (red) $3 \mu \mathrm{s}$, (green) $5 \mu \mathrm{s}$, and (blue) 15-40 $\mu \mathrm{s}$ after the pulse. Optical path = $2 \mathrm{~cm}$, dose per pulse $=80 \mathrm{~Gy}$. 


\section{TDDFT analysis: A characteristic peak for $\left[\mathrm{Ru}^{\mathrm{III}-\mathrm{OH}}\right]^{2+}$}

The difference between the primary excitation in the calculated spectra for the $\left[\mathrm{Ru}^{\mathrm{III}}-\mathrm{OH}\right]^{2+}$ intermediates and a less intense peak due to a LMCT excitation (Figure S13. ) may be considered characteristic for each catalyst. Though the primary excitation occurs at relatively similar wavelengths for each catalyst (see Table S5), this secondary peak occurs at varying wavelengths. In comparing the pulse radiolysis experiment done for $R u$-bpy (Figure S11) to that of $R u$-mbpy (Figure 6 in the text), it is noted that there is a similar peak at around $350 \mathrm{~nm}$. This peak is likely the primary excitation for the $\left[\mathrm{Ru}^{\mathrm{III}}-\mathrm{OH}\right]^{2+}$ intermediate. In considering the difference in wavelength between this primary excitation and the secondary excitation for Ru-bpy, the secondary peak should be observed around $560 \mathrm{~nm}$. However, as seen in Figure S11, this is largely swamped by the signal due to $\mathrm{CO}_{3}{ }^{--}$.

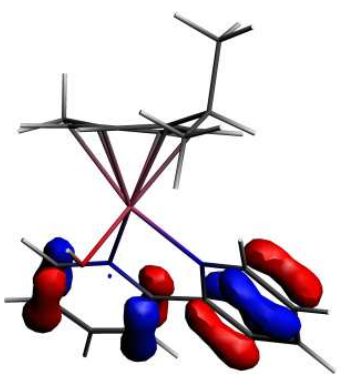

HOMO 8

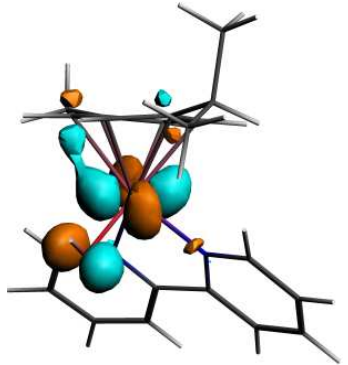

LUMO B

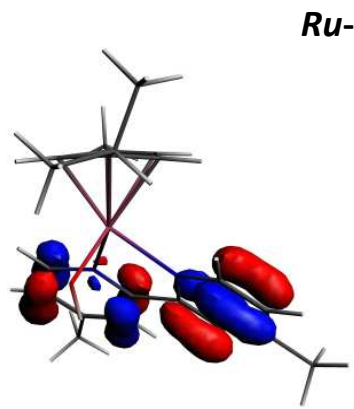

HOMO 8

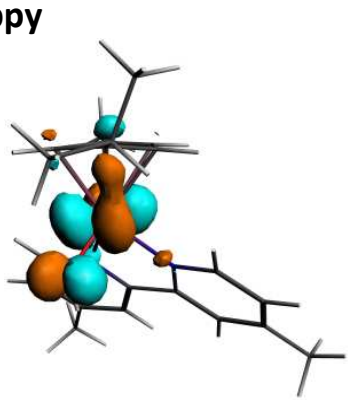

LUMO 8

$R u-m b p y$

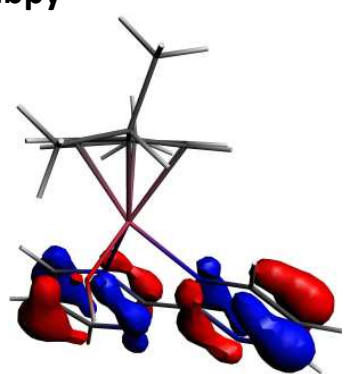

HOMO-2 8

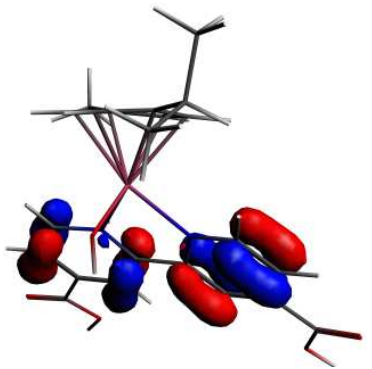

HOMO B

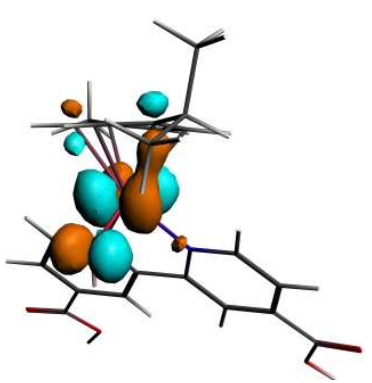

LUMO B

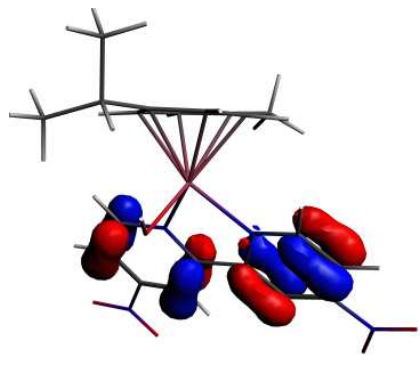

HOMO-2 B

$R u$-bpc

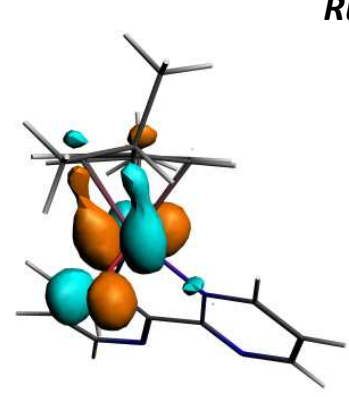

LUMO B

$R u$-bpm

Figure S13. Molecular orbitals involved in the signature excitation around $550-625 \mathrm{~nm}$ for the $\left[\mathrm{Ru}^{\mathrm{III}}-\mathrm{OH}\right]^{2+}$ catalytic intermediate of the different derivative catalysts. 
Pulse radiolysis in acidic solution: rate constant determination

Transient absorption spectra are characterized by the decrease of the typical band of $\mathrm{SO}_{4}{ }^{-{ }^{-}}$at 450 $\mathrm{nm}$ and the increase of two new bands at 340 and $480 \mathrm{~nm}$. The isosbestic point at $400 \mathrm{~nm}$ indicates that the species absorbing at $450 \mathrm{~nm}$ is transformed into the one which absorbs at 340 and $480 \mathrm{~nm}$ without parallel or consecutive reactions, i.e. the reaction follows a first order kinetic and is quantitative.

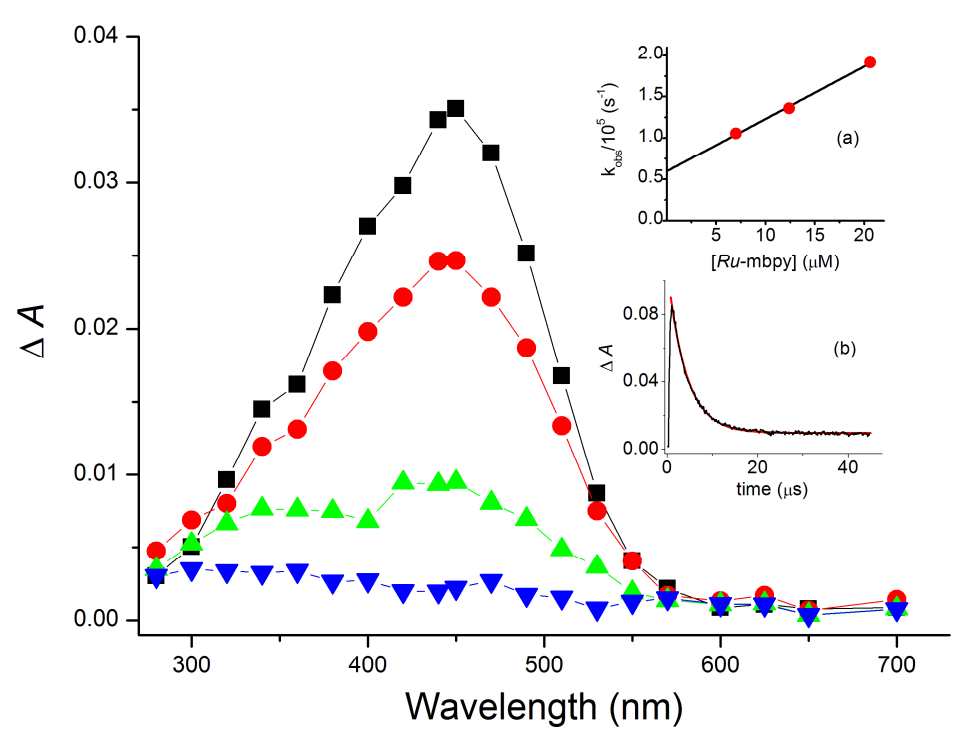

Figure S14. Transient absorption spectra after pulse radiolysis of $R u$-mbpy (c $=7 \mu \mathrm{M}$ ) Ar purged solution containing $0.15 \mathrm{M} \mathrm{K}_{2} \mathrm{~S}_{2} \mathrm{O}_{8}$ and $0.1 \mathrm{M} \mathrm{t}$-BuOH at pH 1.4: (black) $1.25 \mu \mathrm{s}$, (red) $5 \mu \mathrm{s}$, (green) $15 \mu \mathrm{s}$, and (blue) $40 \mu \mathrm{s}$ after the pulse. Optical path $=2 \mathrm{~cm}$, dose per pulse $=38 \mathrm{~Gy}$. Inset (a): Plot of $k_{\text {obs }} v$ s [Ru-mbpy] for the decay at $450 \mathrm{~nm}$ after pulse radiolysis of $R u$-mbpy Ar purged solution containing $0.15 \mathrm{M} \mathrm{K}_{2} \mathrm{~S}_{2} \mathrm{O}_{8}$ and $0.1 \mathrm{Mt}-\mathrm{BuOH}$ at $\mathrm{pH}$ 1.4. Solid line represents the linear regression fit to the data. Inset (b): Graphical representation of Absorbance variation vs. time.

In the experimental conditions that enable the observation of the $\left[\mathrm{Ru}^{\mathrm{III}}-\mathrm{OH}\right]^{2+}$ spectra, it was impossible to evaluate and analyse the kinetic decay of the $450 \mathrm{~nm} \mathrm{SO}{ }_{4}{ }^{-}$absorption (see Figure 5 and Figure S12) because a long-lived transient build-up is superimposed on the decay at $480 \mathrm{~nm}$. 
TDDFT analysis: Primary Excitations for [Ru'II-OH $]^{2+}$

Table S5. Primary excitations for the $\left[\mathrm{Ru}^{\mathrm{III}}-\mathrm{OH}\right]^{2+}$ intermediates of the examined catalysts calculated using TDDFT

\begin{tabular}{llllll}
\hline & $\boldsymbol{R u}$-bpy & $\boldsymbol{R u}$-bpc & $\boldsymbol{R}$ u-mbpy & $\boldsymbol{R}$-dnbpy & $\boldsymbol{R}$ - -bpm \\
\hline$\lambda_{1}(\mathrm{~nm})$ & 416 & 414 & 424 & 438 & 402 \\
$\mathrm{E}_{1}(\mathrm{eV})$ & 2.98 & 2.99 & 2.92 & 2.83 & 3.08 \\
& & & & & \\
$\lambda_{2}(\mathrm{~nm})$ & 627 & 539 & 573 & 554 & 451 \\
$\mathrm{E}_{2}(\mathrm{eV})$ & 1.98 & 2.30 & 2.16 & 2.24 & 2.75 \\
& & & & & \\
$\Delta \lambda(\mathrm{nm})$ & 211 & 125 & 149 & 116 & 49 \\
$\Delta \mathrm{E}(\mathrm{eV})$ & 1.00 & 0.69 & 0.76 & 0.59 & 0.33 \\
\hline
\end{tabular}

\section{Initial investigation of two proposed dimeric intermediates}

Recently there have been a number of, initially monomeric, iridium-based water oxidation catalysts which have been shown to form a dimeric active species. ${ }^{7,8}$ An initial exploration was performed as to the possibility of dimer formation by Ru-bpy using the dimers shown in Figure S15. For each of them, their geometries were optimised, and TDDFT and Raman spectra calculated following the method as described in the text (Computational Method and Details). The lowest energy multiplicity for both the $[\mathrm{Ru}-\mathrm{O}-\mathrm{O}-\mathrm{Ru}]^{4+}$ and the $[\mathrm{Ru}-\mathrm{O}-\mathrm{Ru}]^{4+}$ dimer was found to be a triplet. The results of the spectroscopic calculations are compared to experiment below.

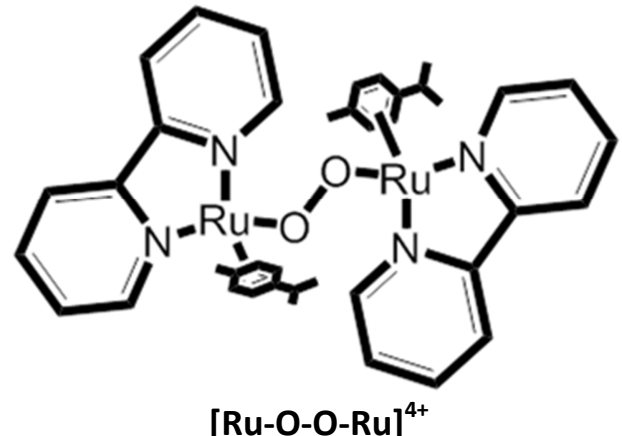

[Ru-O-O-Ru $]^{4+}$

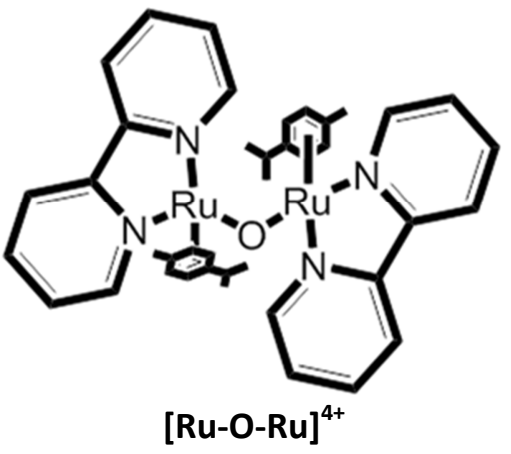

Figure S15. Dimers investigated 
Comparing the calculated TDDFT spectra of the two dimers to the experimental absorption spectrum after 24 hours, there is little agreement. The spectra calculated for the $[\mathrm{Ru}-\mathrm{O}-\mathrm{Ru}]^{4+}$ does show a broad peak around the characteristic wavelength, but does not feature the secondary peak around $400 \mathrm{~nm}$, while the [Ru-O-O-Ru] $]^{4+}$ dimer only shows significant excitations at wavelengths higher than $700 \mathrm{~nm}$ (Figure S16).

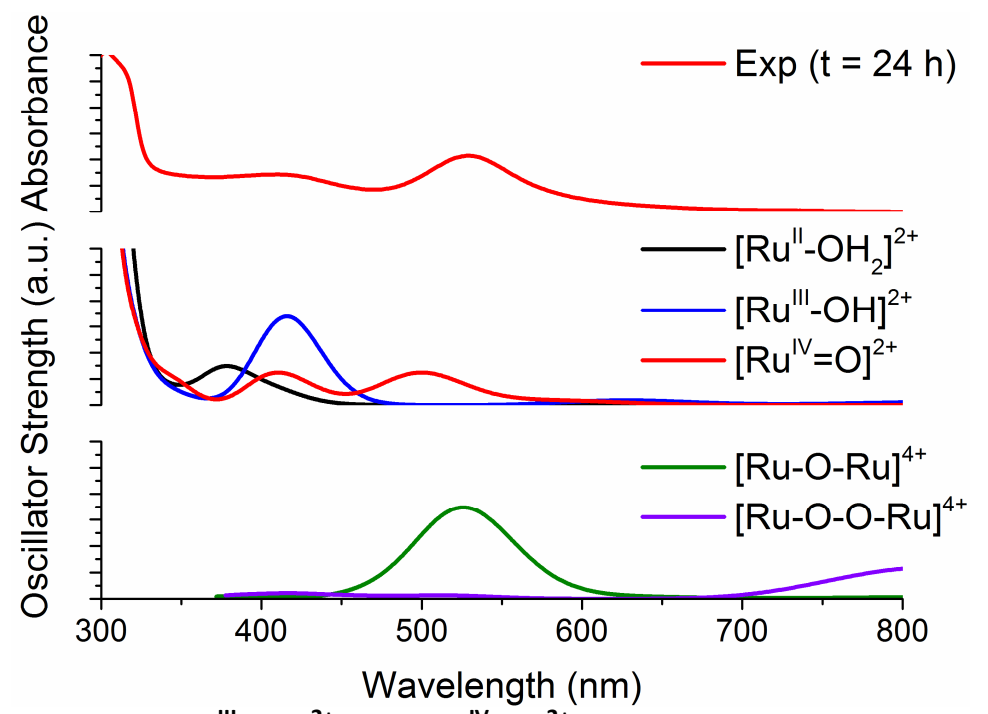

Figure S16 TDDFT spectra of [Ru' $-\mathrm{OH}]^{2+}$ and $\left[\mathrm{Ru}^{\mathrm{IV}}=\mathrm{O}\right]^{2+}$ of $\mathrm{Ru}$-bpy, as well as the two dimers (lower two panels) as compared to experimental absorption spectra after 24 hours upon addition of 10 equivalents of CAN (top panel).

Raman calculations were performed for these dimers following the same methodology described in Computational Method and Details. The conclusions of these calculations are presented below.

\section{Signature Modes Dimers}

- $[\mathrm{Ru}-\mathrm{O}-\mathrm{Ru}]^{4+}$

- Ru-O-Ru bridge modes calculated at $700 \mathrm{~cm}^{-1}$. This is not observed experimentally as it is swamped by the set-up signal

- $\quad[R u-O-O-R u]^{4+}$

O O-O bridge mode calculated at $800 \mathrm{~cm}^{-1}$. This is not observed in the experimental SERS measurement 


\section{References}

(1) Cramer, C. J. Essentials of Computational Chemistry: Theories and Models; Wiley: Chichester, 2005.

(2) Polyansky, D. E.; Muckerman, J. T.; Rochford, J.; Zong, R.; Thummel, R. P.; Fujita, E. J. Am. Chem. Soc. 2011, 133, 14649-14665.

(3) Hug, G. L. Natl. Stand. Ref. Data Syst. 1981, 69, 167.

(4) Buxton, G. V.; Greenstock, C. L.; Helman, W. P.; Ross, A. B. J. Phys. Chem. Ref. Data 1988, 17, 513-886.

(5) Matthews, R. W.; MahIman, H. A.; Sworski, T. J. J. Phys. Chem. 1970, 74, 2475-2479.

(6) Henbest, K.; Douglas, P.; Garley, M. S.; Mills, A. J. Photochem. Photobiol. Chem. 1994, 80, 299305.

(7) Hintermair, U.; Sheehan, S. W.; Parent, A. R.; Ess, D. H.; Richens, D. T.; Vaccaro, P. H.; Brudvig, G. W.; Crabtree, R. H. J. Am. Chem. Soc. 2013, 135, 10837-10851.

(8) Diaz-Morales, O.; Hersbach, T. J. P.; Hetterscheid, D. G. H.; Reek, J. N. H.; Koper, M. T. M. J. Am. Chem. Soc. 2014, 136, 10432-10439. 